\title{
Increased prevalence of myopia in a ophthalmologic hospital in Goiânia - Goiás
}

\author{
Aumento da prevalência de miopia em um serviço \\ oftalmológico de referência em Goiânia - Goiás
}

Mateus Martins Cortez Vilar1, Mayara Martins Abrahão', Denise Borges de Andrade Mendanha', Luana Miranda Campos $^{1}$, Eduardo Ribeiro Coutinho Dalia ${ }^{1}$, Leonardo Pinheiro Teixeira ${ }^{1}$, João Jorge Nassaralla Junior ${ }^{2}$

\begin{abstract}
Objective: To evaluate the increased prevalence of myopia among patients in different periods in an ophthalmologic hospital in Goiânia. Methods: There were compared data collected in two scientific studies carried out in the same ophthalmologic hospital in different periods of time, they evaluated among other factors, the refractive errors of the participants, from this data there were compared the percentage of patients with myopia between the two studies. Results: There was an increase in the prevalence of myopia among the participants of the studies, in the evaluation carried out between 1995 and 2000 the percentage of people with myopia accounted for $3.6 \%$ of the total, in the study carried out in 2014 the prevalence of patients with myopia was $9 \%$. Only among patients with refractive errors the prevalence of myopia in the first study was $9.97 \%$, in the second study the prevalence was $22 \%$. Conclusion: There was an increase in the prevalence of myopia between the two studies, these data corroborate with tests that shows an increasing prevalence of myopia in the world in the last 30 years. However, in a smaller proportion than in other population studies
\end{abstract}

Keywords: Myopia/epidemiology; Refractive errors; Prevalence

\section{RESUMO}

Objetivo: Avaliar o aumento da prevalência de miopia entre pacientes atendidos em períodos diferentes em um serviço oftalmológico de Goiânia. Métodos: Foram comparados dados coletados em dois estudos científicos realizados em um serviço de oftalmologia, em diferentes períodos de tempo, que avaliaram dentre outros fatores, os erros refracionais dos participantes a partir destes dados comparou-se a porcentagem de pacientes portadores de miopia presentes nos estudos. Resultados: Observou-se um aumento na prevalência de Miopia dentre os participantes dos dois estudos. Na avaliação realizada entre 1995 e 2000 a porcentagem de pessoas com miopia representou 3,6\% do total, já no estudo realizado no ano de 2014 a prevalência de pacientes com miopia foi de $9 \%$. Dentre os pacientes com erros refracionais a prevalência de miopia no primeiro estudo foi de $9,97 \%$, já no segundo a prevalência foi de $22 \%$. Conclusão: Observou-se um aumento na prevalência de miopia entre os dois estudos, dados esses que corroboram com análises feitas que mostram um aumento da prevalência de miopia em todo mundo nos últimos 30 anos. Porém em uma proporção menor do que a observada em outros estudos populacionais.

Descritores: Miopia/epidemiologia; Erros de refração; Prevalência

Número de Identificação Clinical Trials: NCT02647411

\footnotetext{
${ }^{1}$ Residence Program in Ophthalmology, Instituto de Olhos de Goiânia, Gioânia, GO, Brazil.

${ }^{2}$ Instituto de Olhos de Goiânia, Gioânia, GO, Brazil.

Study carried out at Instituto de Olhos de Goiânia, Gioânia, GO, Brazil.

The authors declare no conflicts of interests.

Received for publication 23/03/2016 - Accepted for publication 28/08/2016.
} 


\section{INTRODUCTION}

$\mathbf{M}$ yopia occurs when the image of a distant object is formed above the retinal plane, most commonly as a result of an increased axial length. This results in blurred far-sight, and unlike hyperopia, it requires refractive correction at all ages and in all degrees to clear vision. It is already the world's most common refractive error, with its prevalence increasing significantly, especially in Southeast Asia ${ }^{(1)}$.

In Europe, Australia and the United States, its prevalence appears to be lower ${ }^{(2)}$; However, there is evidence of a growing prevalence in the United States and elsewhere ${ }^{(3,4)}$, particularly among young adults ${ }^{(5)}$. This rapid change is not compatible with genetic determination only, and supports the relevance of environmental factors in the pathogenesis of myopia.

Myopia is a complex disorder with a major medical impact on the individuals affected, and with a considerable economic burden for society. Severe myopia is one of the leading causes of visual impairment in the world because it is associated to other ocular comorbidities such as rhegmatogenous retinal detachment, myopic macular degeneration, premature cataracts, and glaucoma. Both genetic and environmental factors have played a role in its pathogenesis ${ }^{(6)}$.

Several environmental factors have been associated to the variation in its prevalence and magnitude, including manual work and outdoor activities during childhood and adolescence, education levels, style of residence (rural vs. urban), and possibly degrees of intelligence ${ }^{(7)}$.

In many Asian countries where the prevalence of myopia has reached epidemic proportions and where the prevalence of high myopia is also very high, it is now recognized as a major public health problem ${ }^{(8-1)}$.

The aim of this study was to compare myopia prevalence data obtained through two epidemiological studies carried out in the same reference service in ophthalmology in the city of Goiânia, Goiás in different periods, and assess whether there has been increased prevalence of this condition in such service in said period between the two studies.

\section{Methods}

We compared data obtained in two studies conducted at Instituto de Olhos de Goiânia between 1995 and 2000 and in 2014 $4^{(12,13)}$.

In the first study, students of the municipal schools of Goiânia were examined during the period between October 1995 and December 2000 (12).

The selection of students who needed ophthalmologic consultation was made by officials of the NGO Fundação Jaime Câmara previously trained by the project coordinator. The criteria for the selection of students for the ophthalmologic consultation were: student enrolled in municipal school; AV $<20 / 30$ uncorrected; presenting previous refractive error, with or without visual correction, strabismus (latent or manifested), external ocular pathology; symptoms related to ocular diseases ${ }^{(12)}$.

The screened students were examined by the residents of Instituto de Olhos de Goiânia, monitored by their faculty members in a mobile unit with two full ophthalmologic offices. The exam consisted of anamnesis, measurement of visual acuity (VA) (optotypes of Snellen, projector Bausch \& Lomb - USA), cover test, measurement near point of convergence (NPC), biomicroscopy (Slit lamp Haag-Streit 900 BM - Swiss), Goldmann applanation tonometry (tonometer Haag-Streit T-900 - Swiss), cycloplegic refraction with cyclopentolate $1 \%$ (Cicloplégico ${ }^{\circledR}$ ) and/or tropicamide 1\% (Mydriacyl®).

The second study selected children from 2 to 14 years of age who were referred to Instituto de Olhos de Goiânia by project Olhar Brasil within the school environment. The project Olhar Brasil aims to identify visual problems related to refraction $^{(13)}$.

Once referred, the children underwent a complete eye exam, which consisted of visual acuity test, external ocular motility exam, biomicroscopy, objective and subjective refractive exam under cycloplegic. It was made after instillation of 1 drop of eyedrops tropicamide 1\% (/Mydriacyl®-Alcon Brazil), and 2 minutes afterwards 1 drop of cyclopentolate (Cicloplégico ${ }^{\circledR}$-AllerganBrazil), and again another drop in each eye of tropicamide $1 \%$ aiming at an effective mydriasis.

For characterization of the main complaints, the parents were questioned the following this criteria: headache, excessive tearing, low visual acuity for far and near sight, purulent secretion, photophobia. The data concerning gender, the main complaints of children, refractive error, and conduct were inserted in the program Excel (MICROSOFT ${ }^{\circledR}$ - USA), and statistically analyzed.

These data was analyzed, and the prevalence of myopia among participants in both general studies was compared to the prevalence of this change among participants with refractive errors, then a possible increase in the prevalence of this condition between the two studies was analyzed.

\section{RESULTS}

In the first study conducted between 1995 and 2000, 16,806 patients between 2 and 40 years were evaluated, with a total of 33,612 eyes (Table 1).

Among these patients, $79 \%$ showed refractive errors, with myopia being present in 2,450 eyes, accounting for 1,225 patients. This represented $3.6 \%$ of the total of participants of the study, and $9.7 \%$ of the total of refractive errors found in the study.

The second study carried out in the year 2014 evaluated 165 patients between 2 and 14 years old, being the total of participants with refractive error found of 68 children, corresponding to $43 \%$ of the total of participants (Table 2).

Among participants with refractive errors, the total of patients with myopia was 15 , corresponding to $22 \%$ of the total refractive errors and $9 \%$ of the total participants (Table 3).

Table 1

Distribution of eyes by refractive error found in the project Boa Visão

\begin{tabular}{lr}
\hline \multicolumn{1}{c}{ Refractive error } & No. of eyes \\
\hline Emmetropia & 8921 \\
Hyperopia & 12908 \\
Myopia & 598 \\
Astigmatism & 2285 \\
Astigmatism + Myopia & 1852 \\
Astigmatism + Hyperopia & 6293 \\
Presbyopia & 628 \\
Infeasible & 127 \\
\hline
\end{tabular}

Source: Nassaralla JJ et al. ${ }^{(12)}$ 
Table 2

Distribution of refractive errors found in Projeto Olhar Brasil

\begin{tabular}{cc}
\hline Refractive error & $\mathbf{N}^{0}$ patients \\
\hline Myopia & 15 \\
Astigmatism & 36 \\
Hyperopia & 41 \\
Emmetropia & 97 \\
\hline
\end{tabular}

Source: Nassaralla JJ et al. ${ }^{(12)}$

Table 3

Comparison between the percentage of myopia in the two studies

\begin{tabular}{cc}
\hline Study & Myopia (\%) \\
\hline Projeto Boa Visão & 3.6 \\
Projeto Olhar Brasil & 9 \\
\hline
\end{tabular}

Source: Vilar MMC et al.

\section{Discussion}

The recent increase in the prevalence of myopia reflects a trend for children in many countries that are spending more time involved in reading, studying or - more recently - looking at the screens of computers and smartphones. The use of devices with ever smaller screens in offices, schools and leisure increased myopia, the difficulty to see in the distance, worldwide, including in Brazil, especially among children ${ }^{(12)}$.

Today, children and youngsters are changing the desktop computer by smartphones or tablets. The smaller screens make most of them hold the equipment at a distance of 25 to $30 \mathrm{~cm}$ from the eye. The visual effort to see so close makes the ocular system lose focus for far sight more easily. The incorrect use of electronics by people with genetic predisposition can cause myopia and compromise the learning ${ }^{(12)}$.

According to data released by the Institute think with Google, Brazil had an increase of $112 \%$ in the share of smartphones between accesses to the internet, and only in the year 2015. Explaining this data is simple, just consider that in 2010 Brazil had 10 million smartphones, and just five years later this number has grown to 93 million $^{(9)}$.

This is particularly the case of the East Asian countries, where the high value given to educational performance is taking children to spend more time in school and studying. A report by the Organization for economic cooperation and development showed that, on average, children of 15 years of age in Shanghai now spend 14 hours a week on homework, compared to 5 hours in the United Kingdom and 6 hours in the United States ${ }^{(13)}$.

A study conducted by researcher Ian Morgan of the Australian National University shows that almost $90 \%$ of young adults from Asian countries - Japan, China, Taiwan, Singapore and South Korea - have myopia ${ }^{(14)}$.

According to the researcher, what was supposed to be a problem with a very strong hereditary load ended up demonstrating the relevant contribution of environment and customs. As a comparison, the percentage of myopic patients in the UK does not reach $30 \%{ }^{(14)}$.
Studies concerning the population of Asians who migrated to other countries are also revealing. Chinese who moved to Australia, for example, where sun exposure is much more common among the youngsters, have lower rates of myopia than their relatives who remain in the country of origin ${ }^{(14)}$.

The data obtained from this study corroborate this trend, even if it shows an increase not so expressive in the prevalence of myopia in the period between the two studies. However, the difference between the age range of the subjects in both projects should be taken into account, as well as the different selection criteria adopted for participants and differences in methodologies between them.

It is important to consider also the big difference between the number of participants in the first study ${ }^{12}$ ) and the second study ${ }^{(13)}$. This is because the first study had a longer period of data collection, five years, in comparison to the second study, one year. However, this fact does not invalidate the comparison, because both were studies carried out in the same service of Ophthalmology following a global trend of increased prevalence of this refractive condition.

The increased requirement for detection and treatment of myopia, which implies glasses, contact lenses, or more recently laser refractive surgery, has significant implications for the ophthalmic services and the health system as a whole. An increase in the provision of ophthalmic services will be needed to treat the possible complications of this condition, such as retinal detachment, glaucoma and cataract $^{(8)}$.

The increased prevalence of myopia also implies that nontreatable complications such as myopic maculopathy, most commonly seen at high myopias, will become more common. This will result in more visual impairment for individuals with a higher age group, including in a large proportion of the population in productive age, with consequent economic implications ${ }^{(8)}$.

Meanwhile, researchers are working on ways to prevent the worsening of myopia. Special glasses and contact lenses are already being developed that can alter the growth of the eye by focusing light from distant images present throughout the field of vision, rather than just the images from the center of vision, as standard lens do ${ }^{(8)}$.

Other research groups have shown that nightly applications of atropine drops at a concentration of $1 \%$ and $0.01 \%$ can also help control myopia progression, although its control mechanism still remains obscure. Other studies were carried out with drugs like pirenzepine and 7-methylxanthine, with satisfactory results, but none of these drugs is approved by the regulatory agencies to control myopia. Preventive treatments based on a scientific analysis of modifiable risk factors would be by far preferable from a public health perspective ${ }^{(8,15)}$.

Although myopia can be relatively easily treated with corrective lenses, it generates substantial costs due to its high prevalence in the population. American data claim that a $25 \%$ prevalence of myopia in people aged from 12 to 54 years generates an annual associated cost of more than 2 billion dollars; an increase in prevalence to $37 \%$ would increase the cost to more than 3 billion dollars annually ${ }^{(16,17)}$.

The issue of whether the prevalence of myopia is increasing is important for health planners and for formatting public policies. The identification of modifiable risk factors for the development of myopia could lead to the development of strategies for cost-effective intervention by governments and educational institutions to contain the advance of this disease ${ }^{(8)}$ 


\section{ConcLusion}

An increase in the prevalence of myopia was observed among the two studies. These data corroborate the analyses showing an increase in the prevalence of myopia in the world in the last 30 years. The increase is smaller than the one found in Asia, but in proportion to the increase found in studies in America and some European countries.

In the future, there should be other studies with closer age groups and with closer numbers of participants to evaluate whether this trend will be kept.

\section{ReFERENCES}

1. Pan CW, Ramamurthy D, Saw SM. Worldwide prevalence and risk factors for myopia. Ophthalmic Physiol Opt. 2012; 32(1):3-16.

2. Kempen JH, Mitchell P, Lee KE, Tielsch JM, Broman AT, Taylor HR, Ikram MK,Congdon NG, O'Colmain BJ; Eye Diseases Prevalence Research Group. The prevalence of refractive errors among adults in the United States, Western Europe, and Australia. Arch Ophthalmol. 2004;122(4):495-505. Erratum in: Arch Ophthalmol. 2005 Oct;123(10):1314.

3. Vitale S, Sperduto RD, Ferris FL 3rd. Increased prevalence of myopia in the United States between 1971-1972 and 1999- 2004. Arch Ophthalmol. 2009; 127(12):1632-9.

4. Parssinen O. The increased prevalence of myopia in Finland. Acta Ophthalmol. 2012; 90(6):497-502.

5. Bar Dayan Y, Levin A, Morad Y. The changing prevalence of myopia in young adults: a 13-year series of population-based prevalence surveys. Invest Ophthalmol Vis Sci. 2005; 46(8):2760-5.

6. Morgan IG, Ohno-Matsui K, Saw SM. Myopia. Lancet. 2012; 379(9827):1739-48.

7. Morgan I, Rose K. How genetic is school myopia? Prog Retin Eye Res. 2005; 24(1):1-38.

8. Rose K, Smith W, Morgan I, Mitchell P. The increasing prevalence of myopia: implications for Australia. Clin Exp Ophthalmol. 2001; 29(3):116-20.
9. Ramaswamy S. How micromoments are changing rules [Internet]. 2015. [cited 2016 Ago 28]. Available from:https://www.think withgoogle.com/articles/how-micromoments-are-changing-rules.html

10. Salinas D. Does homework perpetuate inequities in education? OECD Library, 2014. Available from: http://doi.org/2sd. DOI:10.1787/22260919

11. Dolgin E. The myopia boom. Nature. 2015; 519(7543): 76-8.

12. Nassaralla JJ, Nassaralla Belquiz R. Atendimento no sistema público de ensino de Goiânia - Projeto Boa Visão. Rev Bras Oftalmol. 2002; 61(6):446-52.

13. Mendanha DB, Campos LM, Dalia ER, Teixeira LP, Nassaralla JJ. Análise das principais queixas em crianças encaminhadas pelo Projeto Olhar Brasil em um Hospital Oftalmológico de Goiânia, Goiás, Brasil. Anais. VIII Congresso da Sociedade Brasileira de Oftalmologia. Brasília (DF): SBO; 2015.

14. Morgan, Ian G, Kyoko Ohno-Matsui, Seang-Mei Saw. Myopia. Lancet. 2012; 379 (9827):1739-48.

15. Chia A, Chua WH, Cheung YB, Wong WL, Lingham A, Fong A, Tan D. Atropine for the treatment of childhood myopia: safety and efficacy of $0.5 \%, 0.1 \%$, and $0.01 \%$ doses (Atropine for the Treatment of Myopia 2). Ophthalmology. 2012;119(2):347-54.

16. Vitale S, Cotch MF, Sperduto RD, Ellwein L. Costs of refractive correction of distance vision impairment in the United States, 1999-2002. Ophthalmology. 2006; 113(12):2163-70.

17. Rein DB, Zhang P, Wirth KE, et al. The economic burden of major adult visual disorders in the United States. Arch Ophthalmol. 2006;124(12):1754-60.

\section{Corresponding author:}

Mateus Martins Cortez Vilar

Rua 17-a, no 1461 - Apto. 503 - Setor aeroporto

ZIP Code: 74070-100 -Goiânia (GO), Brazil

FAX: (62) 32202500

E-mail: mateus.vilar@gmail.com 